\title{
Paintings of Ceramic artifacts in the light of the Arabic School
}

\author{
Smah Abdel Rahman Mahmoud ${ }^{\text {a }}$ \\ , Essam Adel Morsi ${ }^{\mathrm{b}}$, \\ Shaaban Samir Abdel Razek ${ }^{\mathrm{c}}$, \\ , Enas Mustafa Abdel Gaber ${ }^{\mathrm{d}}$ \\ ${ }^{a}$ Professor of Tourism Guidance-Faculty of Tourism and Hotels-Minia University \\ ${ }^{b}$ Professor of Islamic Art and Archaeology - Archaeology Department - faculty of Arts - Minia \\ University \\ ${ }^{c}$ Associate Professor of Tourism Guidance-Faculty of Tourism and Hotels-Minia University \\ ${ }^{d}$ Tourism Guidance Department-Minia University
}

\section{Keywords}

Painting

Applied artist

Miniatures

Artist

Decoration

\begin{abstract}
One of the most important reasons for choosing to study this subject is that most Islamic arts depend on photography in desalting their products, such as applied artifacts, examples, such as metals, textiles, ceramics, glass, wood, and others. The multiplicity of art schools of photography, in addition to the long-standing fame that some photographers gained, in addition to the different methods of photography from one school to another, from one art center to another, and from one artist to another.
\end{abstract}




\section{Research importance:}

The importance of studying the paintings of ceramic artifacts in their various forms is to give a valuable and very important overview of the social, economic and cultural life through the pictures of the manuscripts of the Arabic school.

\section{Research aims:}

To shed light on Ceramic artifacts in the paintings of the manuscripts of the Arabic School.

To clarify the similarities and differences between the forms of metal artifacts in the pictures of the manuscripts of the Arab school and their counterparts preserved in different museums.

\section{1.}

Introduction

Researchers and archaeologists pay special attention to antiques made of pottery and ceramics because they are directly related to people's lives from prehistoric times to the present day on the one hand, and because they reflect the inclusion of human life on the ladder of civilization and sophistication in a clear and clear manner on the other hand, and this type of art has developed Industrial pottery ranged from thick-shaped pottery set in the sun, to thin-fish pottery free of decoration, set in the fire, and then from pottery decorated with inscriptions and colors, to pottery in which the skill of the craftsman and the artist's taste was evident ${ }^{(1)}$.

There is no doubt that a number of technicians were involved in the work of ceramic vessels, each of whom naturally had a special task that suited his ability and type of training, and among these are the kneader who prepares the clay for shaping according to the conditions previously mentioned, the potter, the pottery or the fakhuri who shapes the vessels in its initial form, and the kiln who He burns the masterpiece according to what the burning should be like in each stage, and the decorator, painter or painter who paints and makes decorations, a stage in which a number of decorators may participate, Each of them performs a specific task of engraving, drawing or painting, then the masterpiece is transferred to the next person who adds to it in turn, and

so

$$
\text { on }^{(2)}
$$

For the manufacture of Islamic ceramics, winter shrines include, but are not limited to Baghdad, Samarra, Mosul and Kufa in Iraq, Al-Ry, Nashan, Souss and Nisapur in Iran, Fustat, Cairo, Fayoum in Egypt, Raqqa and Al-RSafia and Damascus in Damascus, Malaga, Granada and Manisha in Andalusia, Andalucia, Andacap and

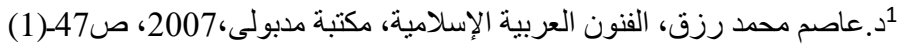

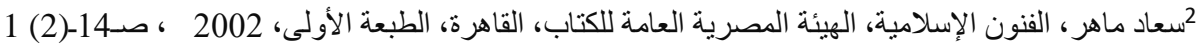


Kutahi in Asia Minor, all these centers and others have produced many crockery and ceramics that included high quality and popular ones

The actual revolution in the manufacture of Islamic ceramics seemed to have begun only before the construction of the city of Samarra in the Abbasid era in Iraq during the century (3 A.H./9 A.D.), the excavations carried out in the ruins of this city resulted in the discovery of a new ceramic form known to art historians as ceramics with metal sparkle ${ }^{(3)}$, a purely Islamic innovation, and its innovation may be due to the desire to satisfy the spirit of luxury among Muslims taking into account the teachings of Islam that forbid the use of gold pots. Silver, and then the potters created a luxurious type with the lustre of gold that satisfies the love of luxury without violating the teachings of Islam.

In fact, this type of Islamic ceramics represents the most important and finest achievement of Muslim craftsmen in this field, as they were able for the first time in the history of this industry to give ceramic pots a shiny metallic luster that combined in its colors golden, copper red and greenish yellow, and this industry has moved The new type of Islamic ceramics after it was known in Iraq during the 3rd century A.H. / 9th A.D. to many different Islamic regions, especially Ray and Susa in Iran, Afraziab (present-day Samarkand) in Asia, al-Zahra in Andalusia, and Fustat in Egypt ${ }^{(4)}$.

As a result of the great development in the manufacture and decoration of ceramic artifacts in all its forms, this had a clear impact on the interest of the Muslim photographer in drawing many of their forms in the pictures of manuscripts, as will be evident from the study review of the forms of ceramic artifacts that appeared in the pictures of manuscripts.

\section{Descriptive study:}

\begin{tabular}{|l|l|}
\hline Plate No. & $\mathbf{1}$ \\
\hline Object Name & $\begin{array}{l}\text { A scene shows a group of robbers } \\
\text { entering on a man and his wife in } \\
\text { their bed room for robbing. }\end{array}$ \\
\hline Name of Manuscript & Kālilā and Dimnā \\
\hline Production Place & Syria \\
\hline Language of Manuscript & Arabic \\
\hline
\end{tabular}

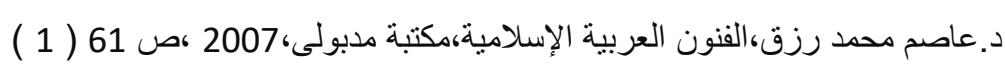

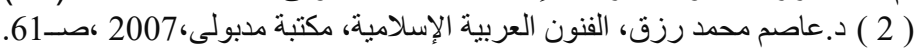




\begin{tabular}{|l|l|}
\hline Calligrapher & Ibn Almoqafa \\
\hline Folio Number & Folio 38 - verso \\
\hline Production Date & $1200-1220$ A.D. / 597 - 617 A.H. \\
\hline Century & 13 th century A.D. / 7th century A. H. \\
\hline Historical Period & Abbasid Period \\
\hline Conservation Town & Paris, France \\
\hline Conservation Place & Bibliothèque Nationale de France \\
\hline Inventory Number & Ms. Arabe 3465 \\
\hline
\end{tabular}

\section{References :}

- Knatchbull (W.), Kālilā and Dimnā or The Fables of Bidpai

translated from the Arabic, London ,1919,P. 70, 71.

\section{Description:}

This miniature shows a scene shows a group of robbers entering on a man and his wife in their bed room for robbing. The thieves are represented entering on a rich man and his wife.in their bed room. In the upper part of the painting and on each sides, we can see two men of thieves climbing up to the top of the house of a rich person through the aperture which was made for admission of light. In the lower part of this painting on the right side, we can see a vase consists of a base that holds a blown body and a long neck carrying a group of flowers.

\begin{tabular}{|l|l|}
\hline Plate No. & 2 \\
\hline Object Name & $\begin{array}{l}\text { The husband beats the lover in the } \\
\text { presence of his wife }\end{array}$ \\
\hline Name of Manuscript & Kālilā and Dimnā \\
\hline Production Place & Syria \\
\hline Language of Manuscript & Arabic \\
\hline Calligrapher & Ibn Almoqafa \\
\hline Folio Number & Folio 39 - verso \\
\hline Production Date & $1200-1220$ A.D. / 597 - 617 A.H. \\
\hline Century & 13 th century A.D. / 7th century A. H. \\
\hline Historical Period & Abbasid Period \\
\hline
\end{tabular}




\begin{tabular}{|l|l|}
\hline Conservation Town & Paris, France \\
\hline Conservation Place & Bibliothèque Nationale de France \\
\hline Inventory Number & Ms. Arabe 3465 \\
\hline
\end{tabular}

References :

- Knatchbull (W.), Kālilā and Dimnā or The Fables of Bidpai

translated from the Arabicm, London,1819, pp. 73.

\section{Description:}

This miniature shows three males and feminine human figures standing inside a simple house, and representing the husband who is the owner of house, his young wife and her lover who is holding by the husband. On the left side, we can see some of vases consist of a base that holds a blown body and a long narrow neck ends with a wide opening carrying a group of flowers.

\begin{tabular}{|l|l|}
\hline Plate No. & $(3)$ \\
\hline Object Name & $\begin{array}{l}\text { A prince sitting on his throne surrounded } \\
\text { by his followers. }\end{array}$ \\
\hline Name of Manuscript & Maqamat al Hariri \\
\hline Number of Maqamah & $\begin{array}{l}15 \text { th Māqamāh (The Māgraābiyā } \\
\text { Māqāmāh) }\end{array}$ \\
\hline Folio Number & Folio 1r ms \\
\hline Language of Manuscript & Arabic \\
\hline Production Date & 1334 A.D. / 734 A.H. \\
\hline Century & $\begin{array}{l}\text { The 14th Century A.D. / the 8th Century } \\
\text { A.H. }\end{array}$ \\
\hline Historical Period & Mamluk Period \\
\hline Conservation Town & Vienna \\
\hline Conservation Place & National Library \\
\hline Inventory Number & A.F.9 \\
\hline
\end{tabular}

\section{References:}

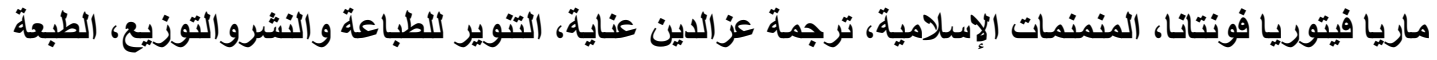

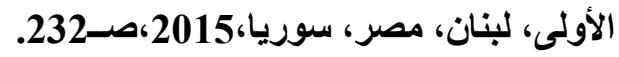

\section{Description:}


This miniature shows a man sitting on his throne surrounded by his followers while holding a cup filled with a drink in his right hand. The cup here is similar to whether preserved in the Museum of Islamic Art in Cairo, or what appeared from them in manuscript paintings.

\begin{tabular}{|l|l|}
\hline Plate No. & 4 \\
\hline Object Name & $\begin{array}{l}\text { Abu Zāyd and āl- harit during a } \\
\text { meeting of glee inside a tavern in } \\
\text { the presence of men and a dancer } \\
\text { girl. }\end{array}$ \\
\hline Name of Manuscript & Māqamāt of āl-hāriri \\
\hline Production Place & Egypt \\
\hline Language of Manuscript & Arabic \\
\hline Calligrapher & Yāhyā ibn Māhmud āl-Wāsiti \\
\hline Folio Number & Folio 33 - recto \\
\hline Production Date & 3 May 1237 A.D. / 6 Ramadan 634 \\
\hline Century & A.H. \\
\hline Historical Period & The 13th century A.D. / the 7th \\
Contury A.H.
\end{tabular}

\section{References:}

صلاح حسين العبياى،الملابس العربية الإسلامية فى العصر العباسى من المصادر التاريخية،دار الرشيد للنشر،بغداد،1980،صــ214.

- Grabar (O.), the Illustrations of the Maqamat, Chicago, University of Chicago press, 1984 , p. 47.

\section{Description:}

This miniature shows the story of this Maqamah tells us that al- harith, son of Hammam, and a group of companions, after having them enjoyed the pleasures of Damascus, want to return to Iraq, but they can find no one to guide them through the 
dangers of the desert. They are assembled on the outskirts of the town to discuss the problem when a youth in the garb of a holy man offers to lead then and, as a safeguard against all dangers, recites an incantation over a strange talisman. The travelers learn it and cast lots to see whose mount will carry the holy man. Abu Zayd is shown holding a small cup in his left hand, in the upper part of the painting, we can see two men each of them holds a cup in his hand.

\begin{tabular}{|l|l|}
\hline Plate No. & 5 \\
\hline Object Name & $\begin{array}{l}\text { A scene shows a king and his } \\
\text { daughter in the presence of a } \\
\text { physician. }\end{array}$ \\
\hline Name of Manuscript & Kālilā and Dimnā \\
\hline Production Place & Syria \\
\hline Language of Manuscript & Arabic \\
\hline Calligrapher & Ibn al-Muqaff \\
\hline Folio Number & Folio 78 - verso \\
\hline Production Date & $1200-1220$ A.D. / 597 - 617 A.H. \\
\hline Century & 13 th century A.D. / 7th century A. H. \\
\hline Historical Period & Abbasid Period \\
\hline Conservation Town & Paris, France \\
\hline Conservation Place & Bibliothèque Nationale de France \\
\hline Inventory Number & Ms. Arabe 3465 \\
\hline References : &
\end{tabular}

\section{References :}

أبو الحمد محمود محمد، تصاوير المخطوطات فى عصر الأيوبيين دراسة آثرية فنبة، مخطوط رسالة ماجستير

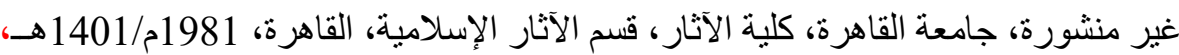

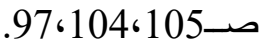

translated from the Knatchbull (W.), Kālilā and Dimnā or The Fables of Bidpai Arabic, Op. Cit., pp. 175, 176.

\section{Description:}

This painting depicts on the right side a king, in the middle his daughter and the other side a physician. The whole scene is painted inside the palace of the king. The miniature shows the story of the man, who claimed that he is a physician, where he mixed the poison with medication to kill the daughter of the king, but the king 
punished the physician via the drinking from the same medication to die him at once. The physician is represented holding a dish.

\begin{tabular}{|l|l|}
\hline Plate No. & 6 \\
\hline Object Name & $\begin{array}{l}\text { A scene represents a doctor who wakes } \\
\text { up to find a feast inside his house. }\end{array}$ \\
\hline Name of Manuscript & $\begin{array}{l}\text { Da 'wat ā l ātibba or Banquet of The } \\
\text { Physicians }\end{array}$ \\
\hline Language of Manuscript & Arabic \\
\hline Production Date & $\begin{array}{l}\text { 4 th December 1272 A.D. / 10th } \\
\text { Jumada al-Awwal 671 A.H., }\end{array}$ \\
\hline Century & 13 th century A.D. / 7th century A. H. \\
\hline Historical Period & Mamluk Period \\
\hline Conservation Town & Milan, Italy, \\
\hline Conservation Place & Biblioteca Ambrosiane \\
\hline Inventory Number & Ms. A.125 \\
\hline
\end{tabular}

\section{Description:}

The miniature shows a doctor wakes up from his sleep to find a feast in his home. The artist painted a form of ceramic dishes, a form closer to a bowl with a spherical body and a small, oppressive base that is wide from the bottom and then takes in distress whenever it reaches the part attached to the body of the dish and these pots were used to save some types of food or drink, as they appear in the photography where a person catches them sitting in front of a dining table.

\begin{tabular}{|l|l|}
\hline Plate No. & $(7)$ \\
\hline Object Name & $\begin{array}{l}\text { A scene represents a young girl as a } \\
\text { servant bringing food to Abu Zayd and } \\
\text { al-Harith }\end{array}$ \\
\hline Name of Manuscript & Mqāmāt of Āl-hāriri \\
\hline Number of Maqamah & 15 th Maāqāmāh \\
\hline Folio Number & Folio 40 - verso \\
\hline Page No. & 40 \\
\hline Language of Manuscript & Arabic \\
\hline Calligrapher & $\begin{array}{l}\text { 'mar ben 'li ben Al-Moubārāk Al- } \\
\text { Māwsili }\end{array}$ \\
\hline Illustrator (Painter) & $\begin{array}{l}\text { 'mar ben 'li ben Al-Moubārāk Al- } \\
\text { Māwsili }\end{array}$ \\
\hline
\end{tabular}




\begin{tabular}{|l|l|}
\hline Production Place & Mosul, Iraq \\
\hline Production Date & 1256 A.D. / 654 A.H. \\
\hline Century & $\begin{array}{l}\text { The 13th Century A.D. / the 7th Century } \\
\text { A.H. }\end{array}$ \\
\hline Historical Period & Mamluk Period \\
\hline Conservation Town & London, England \\
\hline Conservation Place & British Library \\
\hline Inventory Number & Ms. Or. 1200 \\
\hline
\end{tabular}

References :-

- Grabar (O.), The Illustrations of the Maqamat, Chicago, University of Chicago press, 1984, pp. 13, 52, 53, 54 .

\section{Description:}

This scene is painted inside a house with an arched frame where it belongs to a known man called the Shaykh. On the right side, we can see, the Shaykh sitting on the ground in the position of cross-legged for having the food with Abu Zayd. He is shown wearing a white headdress on his head and a green long and wide garment on his body. The Shaykh is represented with two eyebrows, two black eyes, a mustache and long black beard. He is depicted pointing to Abu Zayd to have food with him. His head is shown surrounding by a circle halo around it. A young girl standing in the middle of the painting holds a jug in its form that corresponds to the previous jugs consisting of a blown body, a long neck and a small base.

\begin{tabular}{|l|l|}
\hline Plate No. & 8 \\
\hline Object Name & $\begin{array}{l}\text { A scene shows a sitting king on a } \\
\text { throne and in front of his wives Irāhat } \\
\text { and hourkanat }\end{array}$ \\
\hline Name of Manuscript & Kālilā and Dimnā \\
\hline Production Place & Egypt \\
\hline Language of Manuscript & Arabic \\
\hline Calligrapher & Unknown \\
\hline Folio Number & Folio 106 - verso \\
\hline Production Date & Around 1500 - 1699 A.D. / 900 - \\
& 1095 A.H. \\
\hline Century & The 16th - 17th Century A.D. / 10th - \\
\hline
\end{tabular}




\begin{tabular}{|l|l|}
\hline & 11 th Century A.H. \\
\hline Historical Period & The Ottoman period \\
\hline Conservation Town & Munich, German \\
\hline Conservation Place & Bavarian State Library \\
\hline Inventory Number & Cod. Arab. 615 \\
\hline
\end{tabular}

\section{References :}

translated from the Knatchbull (W.), Kālilā and Dimnā or The Fables of Bidpai Arabic, Op. Cit., pp. 327, 328.

\section{Description:}

This miniature shows a scene representing a sitting king on a throne and in front of him Irāht and hourkanat. In the middle of the painting, we can see the second wife of the king who is Ira h t. She is represented standing in between hourkanat and the king, and wearing a dress with two pieces of different colors. The first piece of the garb, it is most probably a qamis, carries the dark brown color and covers the lower part of her body while the other piece holds the green color and covers the upper part of her body. She is shown holding a deep dish of rice with his right hand.

\begin{tabular}{|l|l|}
\hline Plate No. & $(9)$ \\
\hline Object Name & $\begin{array}{l}\text { A man helps a pharmacist during } \\
\text { preparing the medicine. }\end{array}$ \\
\hline Name of Manuscript & Dioscorides's Materia Medica \\
\hline Author & Dioscorides Pedanius \\
\hline Language of Manuscript & Arabic \\
\hline Calligrapher & 'bdallah ben Al-Fadl \\
\hline Illustrator (Painter) & 'bdallah ben Al-Fadl \\
\hline Production Place & Baghdad, Iraq \\
\hline Production Date & $\begin{array}{l}\text { July/August 1224 A.D. / Rajab 621 } \\
\text { A.H. }\end{array}$ \\
\hline Century & $\begin{array}{l}\text { The 13th Century A.D. / the 7th Century } \\
\text { A.H. }\end{array}$ \\
\hline Historical Period & Abbasid Period \\
\hline Conservation Town & Istanbul, Turkey \\
\hline
\end{tabular}




\begin{tabular}{|l|l|}
\hline Conservation Place & Aya Sofya, later Top Kapi Seray \\
\hline Inventory Number & $\mathbf{3 7 0 3 , 2 1 4 7}$ \\
\hline
\end{tabular}

\section{References :}

Halil (T.), Dioscorides' Materia Medica Manuscripts in Turkey,

No date.

\section{Description:}

In the upper part of this miniature we can see, a group of pots and it is noted that these pots were used to preserve liquids, herbs and acids that were used in the various pharmaceutical

industries.

\begin{tabular}{|l|l|}
\hline Plate No. & $\mathbf{( 1 0 )}$ \\
\hline Object Name & $\begin{array}{l}\text { Three of thieves entering on a man } \\
\text { and his spouse in their private room }\end{array}$ \\
\hline Name of Manuscript & Kālilā and Dimnā \\
\hline Production Place & Egypt \\
\hline Language of Manuscript & Arabic \\
\hline Calligrapher & Unknown \\
\hline Folio Number & - verso29Folio \\
\hline Production Date & $\begin{array}{l}\text { Around 1500 - 1699 A.D. / 900 -1095 } \\
\text { A.H. }\end{array}$ \\
\hline Century & $\begin{array}{l}\text { The 16th - 17th Century A.D. / 10th - } \\
11 \text { th Century A.H. }\end{array}$ \\
\hline Historical Period & The Ottoman period \\
\hline Conservation Town & Bavarian State Library \\
\hline Conservation Place & Cod. Arab. 615 \\
\hline Inventory Number & Munich, German \\
\hline
\end{tabular}




\section{References:}

Knatchbull (W.), Kālilā and Dimnā or The Fables of Bidpai translated from the Arabic, London, 1819, pp. 70, 71.

\section{Description:}

This miniature shows the story of the thief, who having formed with some of his companions a plan for robbing a rich man and his spouse. The thieves are represented entering on a rich man and his spouse.in their private room. In the lower part of this painting to the left side, we can see a beautiful vase carrying a group of flowers.

\section{Analytical Study:}

Vase is one of the types of Islamic artifacts that the Muslim artist was interested in making in various forms and from different materials, the most widespread of which were ceramic vases, and even reached the importance of that type of artifacts that the artist decorated many artifacts of different materials in the forms of vases and branches came out of them The leaves are fruitful and the vase industry has continued throughout Islamic times due to the nature of its function, carrying roses and botanical branches that give the place a kind of joy and a sense of comfort.

It is clear from the foregoing that some forms of vases are similar to what we got from them, and from them, and in general it can be said that this type of ceramic masterpiece was of little manufacture because its use was limited to a certain class of people, which we cannot call the aristocracy only, but it is possible That there are members of the common people, but her sense of nature and its beauty made her acquire such vases, meaning that they are not limited to a limited class as much as their use was limited to a special type of people. Therefore, their drawings are few in manuscript images, as were the numbers made and preserved in some museums. The shapes of the vases came to us, and among the similar ones that were drawn in the pictures of manuscripts, we notice that they are similar in some parts and differ in some of them.

However, it is clear that all the drawings of vases in the pictures of manuscripts were painted accurately and clearly expressing the general form of it, as it also expressed the function of the masterpiece, as all its drawings were placed in the forms of flowers and roses to express its function in addition to showing the aesthetic and decorative features that such quality adds. From antiques to where they are placed.

And cups are one of the most important ceramic vessels that have been used throughout the ages. They were not only ceramic cups, but cups were made of some other materials such as glass and metal. Perhaps what makes us put them among ceramic masterpieces is the presence of some of these cups preserved in the Museum of Islamic Art in Cairo, which represents the usual form of such antiques, as it expands From its upper opening, it narrows at the base and carries inscription 
decorations that go with the outer frame of the upper part and spread over the entire body of the cup under this frame, and other One of the examples of ceramic cups, which is one of the strong reasons through which it can be said that what appeared in the pictures of the manuscripts of the Arabic school of cups in this way indicates that they were made of porcelain, and there is another reason that confirms this, as the artist painted some of these cups in some pictures of manuscripts as if they were Transparent, as well as the artist showed the drink inside it by coloring nearly twothirds of the cup in a dark color, indicating that this color represents the inner drink, and thus he indicates that this cup is made of glass, given that the glass is characterized by transparency, so that what is inside the cup appears unlike the ceramic cups.

The shapes of the dishes in the pictures of the manuscripts of the Arabic school varied, including the simple shape that closely resembles the dishes made of enameled pottery, and some of them were painted in a more profound way.

The artist was interested in drawing the pots in the paintings of manuscripts which were used to preserve liquids, herbs and acids that were used in the various pharmaceutical industries.

\section{CONCLUSION}

The applied artifacts in all their forms and shapes were the most prominent contents of the manuscript, and the artist's use of the forms of these artifacts had more than one meaning: the first meaning referred to the place where the subject and events of the picture took place.

The second meaning: Referring to the function of the masterpiece, because the artist did not draw it in vain or entered the picture, but rather drew it to clarify its true function.

The third meaning: the decorative aspect. It was an urgent desire among the artists of the Islamic era. The decorative aspect was one of the first concerns of the Muslim artist.

One of the most prominent ceramic artifacts that appeared in the pictures of manuscripts are vases, some of which are similar to what we have come from, and also what appeared a little different, but in general it can be said that this type of ceramic artifact was small in manufacture since its use was limited to a certain layer of people we can not only call it the aristocracy, but it is possible that there are members of the general people but its sense of nature and beauty made it acquire such as These vases.

By comparing the forms of vases that have come down to us and those painted in manuscript images, we notice that they are similar in some parts and differ in others. 
As for the ceramic cups, what appeared from them in the manuscript images is quite similar to what appeared from them in the museums. It is noticeable in the drawings of the cups that they were a small body at the base and expanded at the mouth, and some of these cups did not show any kind of decoration that appeared in the cups.

As for the dishes, they are very similar to those displayed in museums.

Likewise, pots, although their appearance in manuscripts was limited, and pots in pictures of Arabic school steps were similar to those preserved in museums.

\section{References:}

أبو الحمد محمود محمد، تصاوير المخطوطات فى عصر الأيوبيين دراسة آثرية فنية، مخطوط رسالة ماجستير

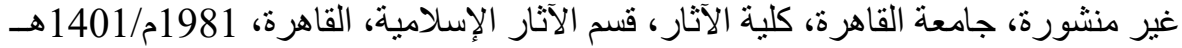

زكى حسن، فنون الإسلام، مكتبة النهضة المصرية، القاهرة،1948 .

سعاد ماهر، الفنون الإسلامية، الهيئة المصرية العامة للكتاب، القاهرة، الطبعة الأولى،2002 .

صلاح حسين العبيدى،الملابس العربية الإسلامية فى العصر العباسى من المصادر التاريخية،دار الرشيد للنشر ،بغداد،1980.

عاصم محمد رزق، الفنون العربية الإسلامبة،مكتبة مدبولى،القاهرة،2007.

ماريا فيتوريا فونتانا،المنمنمات الإسلامية،رجمة عزالدين عناية،التنوير لطباعة والنشروالتوزيع،الطبعة

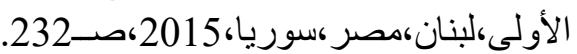

Grabar (O.), the Illustrations of the Maqamat, Chicago, University of Chicago Press, 1984.

Halil (T.), Dioscorides' Materia Medica Manuscripts in Turkey,No date.

Knatchbull (W.), Kālilā and Dimnā or The Fables of Bidpai translated from the Arabic, London, 1819. 


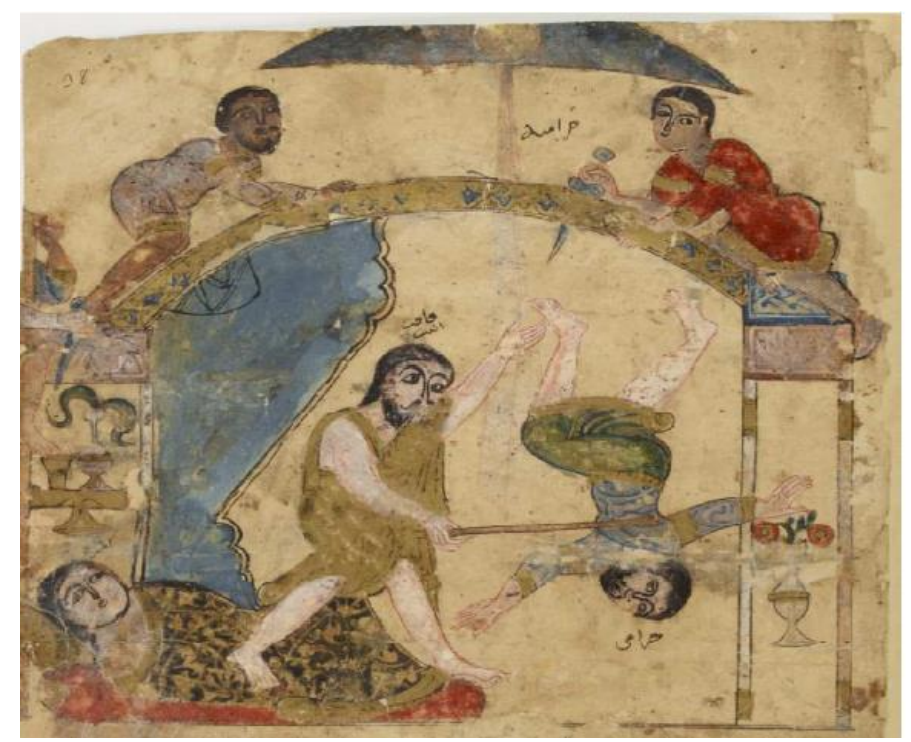

PL.1. A scene shows a group of robbers entering on a man and his wife in their bedroom for robbing, Syria, ,1200-1220A.D./597-617A.H.Pairs, Bibliotheque Nationale de France,Ms.arabe 3465,fol.38v(28x20,5cm) (After the Manuscript of Kālilā and Dimnā in Bibliotheque Nationale de France.

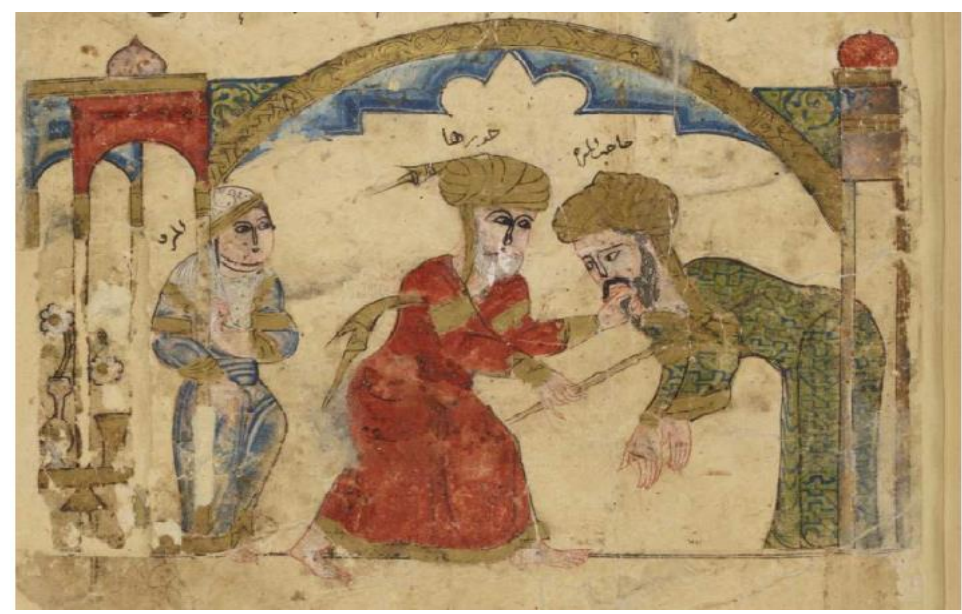

PL.2. The husband beats the lover in the presence of his wife, Syria,,12001220A.D./597-617A.H.Pairs, Bibliotheque Nationale de France, Ms.arabe 3465,fol.39v(28x20,5cm)(After the Manuscript of Kālilā and Dimnā in Bibliotheque Nationale de France. 


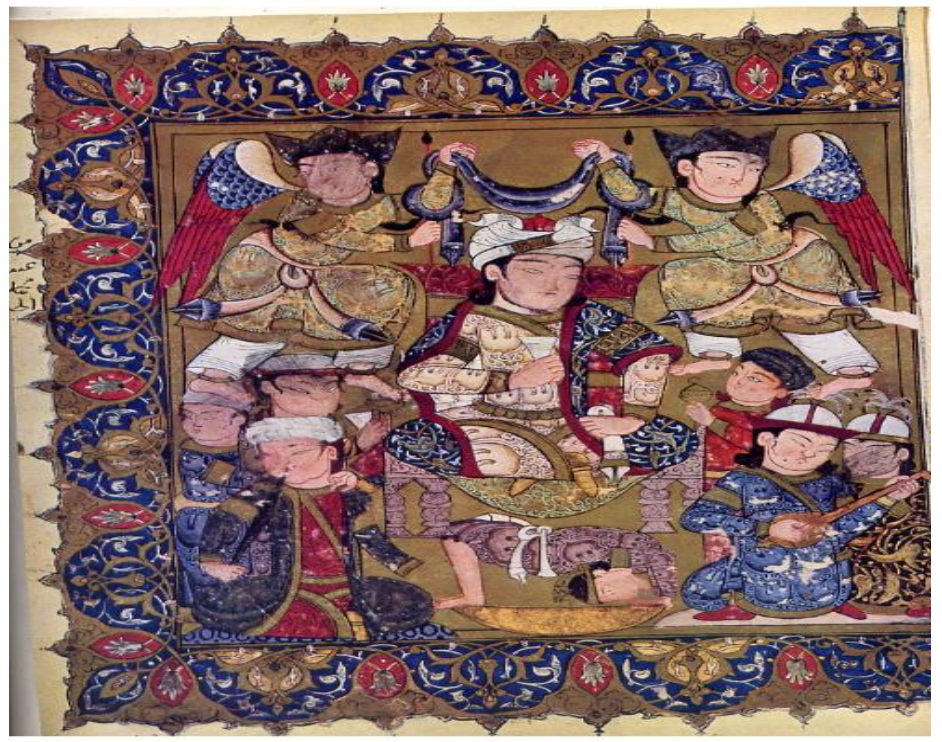

Pl.3 A prince sitting on his throne surrounded by his followers, manuscript of Maqamat āl-ḥāriri,734 A.H./1334 A.D.,( $8^{\text {th }}$ A.H./14 ${ }^{\text {th }}$ Century A.D.), National Library in Vienna,

(A.F.9,fol.1r ms.).

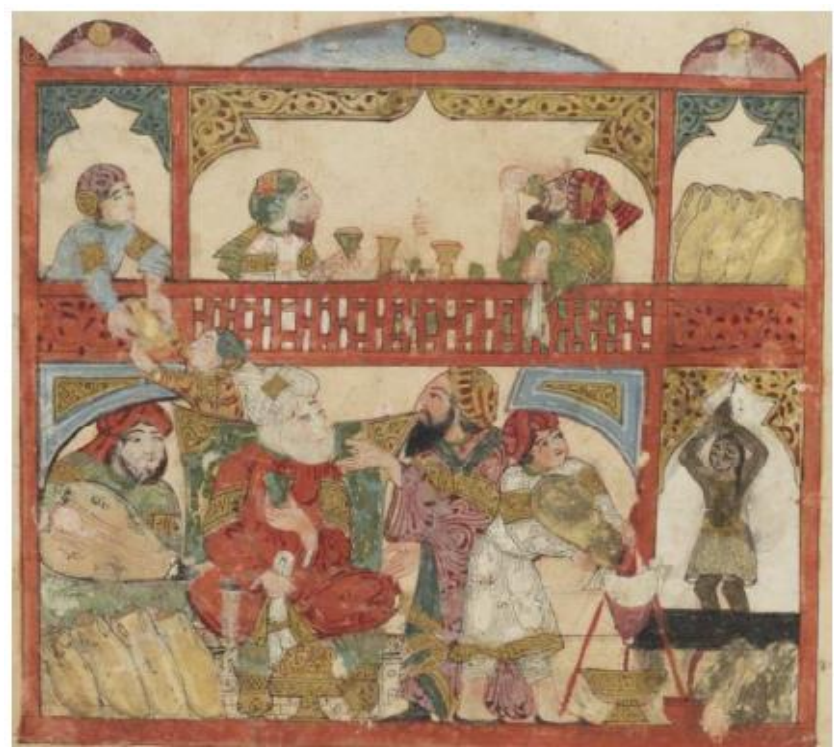

Pl.4.Abu Zāyed and al-hairth during a meeting of glee inside a tavern in the presence of men and a dancer girl (The 12 th Maqamah),1237A.D./634A.H.., (13 ${ }^{\text {th }}$ Century A.D./ $7^{\text {th }}$ A.H.), ) copied and illustrated by al-Wasiti,Paris, Bibliotheque Nationale de France,Ms.arabe 5847, fol.13v(37x28cm)(After the Manuscript of Maqamat of ālḥāriri in , Bibliotheque Nationale de France. 


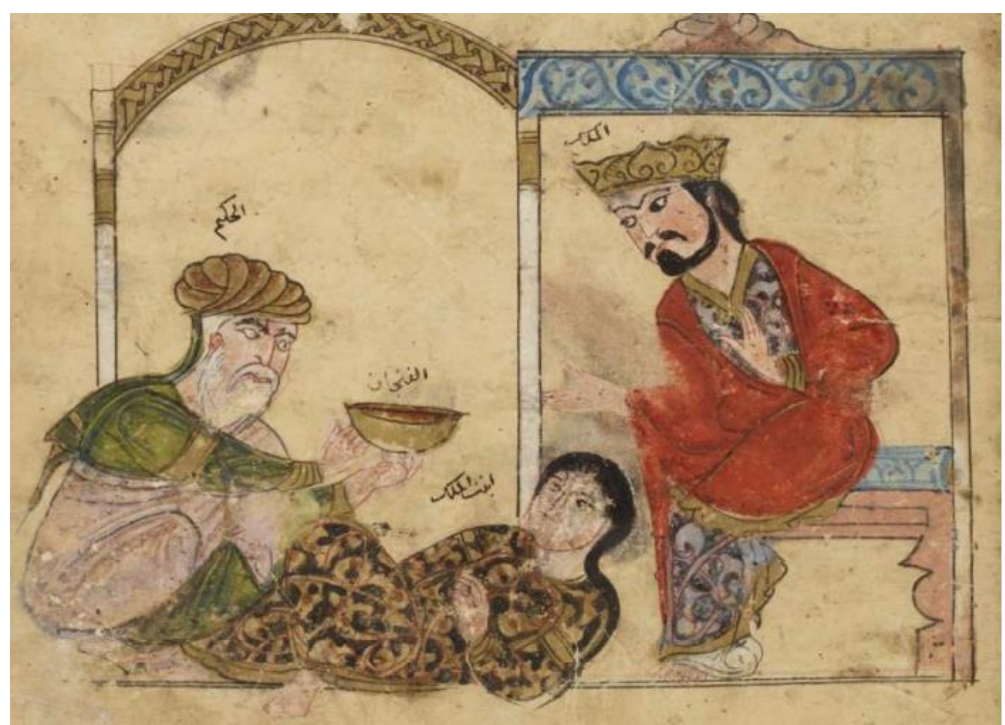

PL. 5. A scene shows a king and his daughter in the presence of a physician ,Syria, ,1200-1220A.D./597-617A.H.Pairs, , Bibliotheque Nationale de France,Ms.arabe3465,fol.78v(28x20,5cm)(After the Manuscript of Kālilā and Dimnā in Bibliotheque Nationale de Franceh.

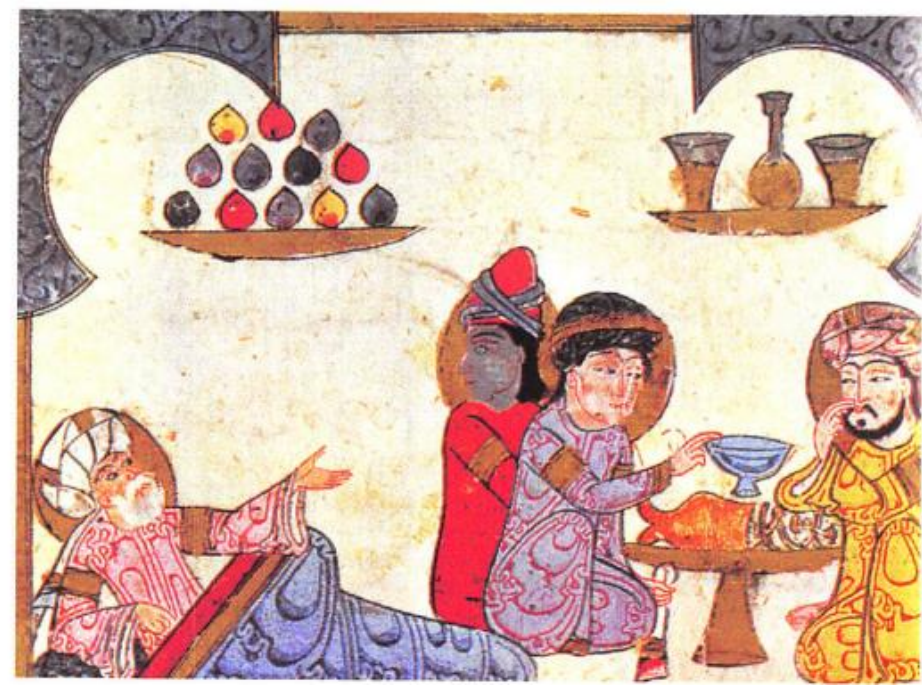

PL.6 A scene represents a doctor who wakes up to find a feast inside his house, Da'wat al Atibba or Banquet of The Physicians, 4 th December 1272 A.D. / 10th Jumada al-Awwal 671 A.H., Mamluk Period, Milan, Italy, Biblioteca Ambrosiane, Ms. A. 125 inf. 


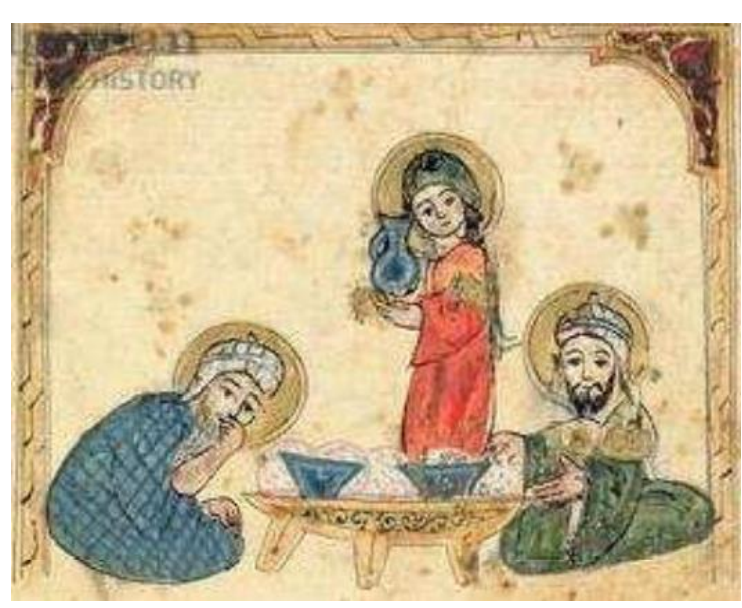

PL.7.A scene represents a young girl as a servant bringing food to Abu Zāyed and al Harith (The $15^{\text {th }}$ Maqamah),Mousl,Iraq,1256a.d./645a.h.(13 ${ }^{\text {th }}$ century A.D. $/ 7^{\text {th }}$ century A.H.),London,Britich Library,Ms.Or.1200 fol.40v(page size $24.5 \times 17 \mathrm{~cm}$, with restoration,Originally $24,5 \times 15,5 \mathrm{~cm})($ After Grabar(o).the illustrations of the Maqamat Chicago:press, 1984,pp.13,52,53,54)

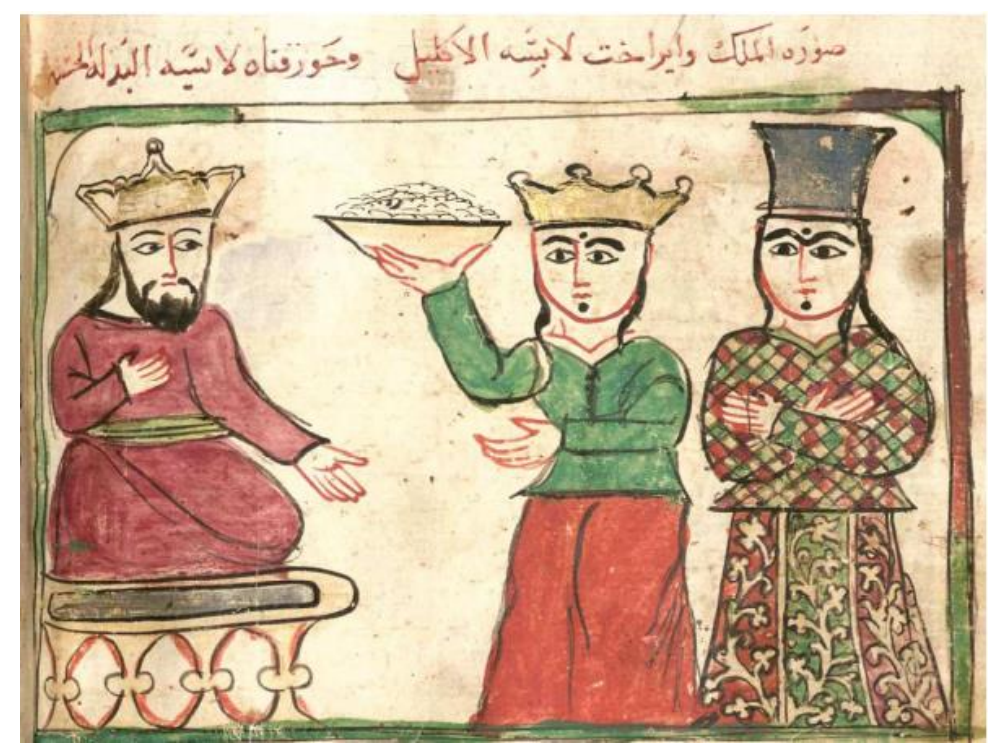

PL. 8 A scene shows a sitting king on a throne and in front of his wives Irakht and Hourkanat, in their private room ,Date is unknown, Munich, German,Bavarian State Library,Cod.Arab.615,fol.108r(28x18.5cm)(Ater the Manuscript of Kālilā and Dimnāin Bavarian State Library,Munich,German). 


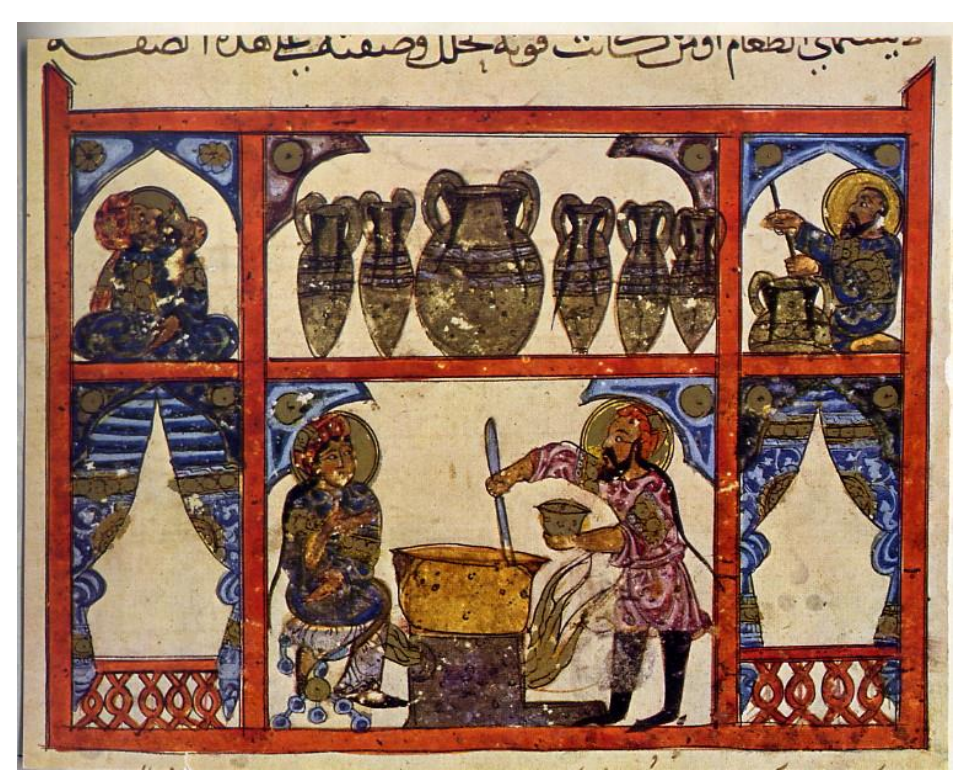

P1.9 A man helps a pharmacist during preparing the medicine,Baghdad,Iraq,1224 A.D./621A.H.,(13 ${ }^{\text {th }}$ Century $/ 7^{\text {th }}$ A.H.),New Yourk,Metropolitan,Museum of Art,W.675,page size33,5x24.9cm. Manuscript of Dioscoridess Materia Medica.

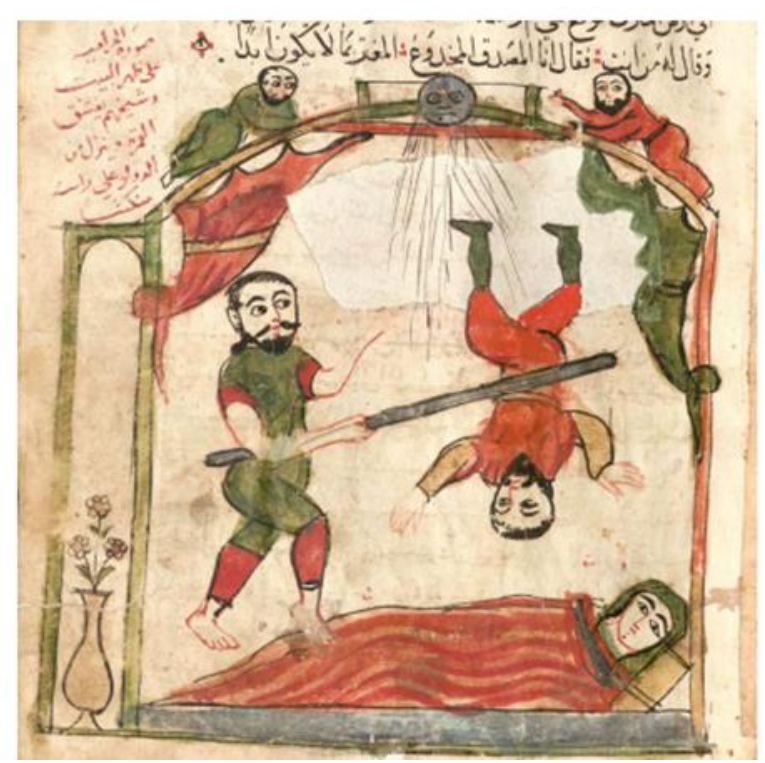

PL.10.Three thieves entering on a man and his wife in their private room, Date is Munich, German, Bavarian State unknown, Library,Cod.Arab.615,fol.29v(28x18.5cm)(After the Manuscript of Kālilā and Dimnā in Bavarian State Library, Munich, German). 